\title{
Special Economic Zone IPT "Lotus" as the Tool of Activization for the Region's Innovative Activity
}

\author{
Elena P. Karlina \\ Astrakhan State Technical University \\ Institute of Economics \\ Astrakhan, Russia \\ e_karlina@list.ru
}

\author{
Anastasia S. Kovalenkova \\ Astrakhan State Technical University \\ Institute of Economics \\ Astrakhan, Russia \\ fartuschina@yandex.ru
}

\author{
Irina I. Potapova \\ Astrakhan State Technical University \\ Institute of Economics \\ Astrakhan, Russia \\ ipotapowa@list.ru
}

\begin{abstract}
Special economic zones of the industrialproduction type are created in accordance with the legislation in order to develop the processing and high-tech industries, so it is possible to consider these structures to be the tools for improving innovative activity, as an integral component of modernization of industrial production. The SEZ "Lotus" created in the Astrakhan region is defined at the Federal level as a main platform for localization the production of the equipment and accessories in shipbuilding industry in the South of Russia and can be used for formation the pool of small innovative enterprises and shipbuilding enterprises allowing accumulating their financial resources for development and commercialization of innovative products and technologies.
\end{abstract}

Keywords - special economic zone, innovations, region, shipbuilding, pool, small innovative enterprises

\section{INTRODUCTION}

Improving the competitiveness of the Russian economy in the face of global challenges is possible only if it achieved high productivity rates by stimulating the development and implementation of advanced technologies which productivity significantly exceeds the characteristics of traditional ones. At the same time, according to the CSR, choosing the priority areas of accelerated development, the rate should be made both on the advanced development of absolutely new hightech sectors and markets, and on the deep technological modernization of traditional industries and productions [1].

In this regard, the intensification of innovation should be carried out both in the national economic system and in all constituent entities within the RF. The creation of special economic zones (SEZs) in Russia is one of the tools for the implementation of modern innovative and industrial policy, the objectives of which are the reindustrialization of industrial production based on the priority of the development and implementation of technological innovations taking into account new trends in the world economy. The special economic zones of technical and promotional type created within the RF Federal law №116 "About special economic zones" should also contribute to the development of innovation activity [2]. However, according to the study and analysis of functioning SEZ in the Russian Federation it is possible to make a conclusion about the appropriateness of discussing the place and role of other SEZ types for enhancing the innovation activities, in particular the SEZ of industrialproduction type (IPT).

\section{MATERIALS AND METHODS (MODEL)}

Special economic zones of industrial-industrial type are one of the forms of public-private partnership that makes it possible to balance the interests of the state, business and the region as a socio-economic system through the use of cofinancing mechanisms and the distribution of risks of investment projects.

The creation of a special economic zone of industrialproduction type "Lotus" (SEZ IPT "Lotus") in the Narimanov district of the Astrakhan region was caused by the need to set up a local chain of shipbuilding and engineering products as a result of the integration into a single process of all shipbuilding production elements: electrical engineering, machinery, instrumentation, automation, production of modern materials, marine textiles and furniture, which allows in combination with proximity to markets and benefits provided by the special economic zone, ensuring a significant reduction in the cost of implementing investment projects of residents. The main advantages of the SEZ "Lotus" are: 
designation at the Federal level as the main placed for the localization the production of equipment and components in shipbuilding industry; orientation to the production of hightech products in the field of import-substituting projects, providing the leading position of Russia in the world market; the most attractive conditions of taxation among industrialproduction zones in the Russian Federation [3].

The Astrakhan region ranks fourth in terms of development of innovative activity in the Southern Federal
District, while the structure of costs for technological innovations in 2016 is characterized as the most progressive among the constituent entities within the Southern Federal District, due to the high ratio of costs for the acquisition of new technologies for the development and operation of offshore hydrocarbon deposits in the Northern Caspian Sea (Figure 1).

The functioning of the SEZ "Lotus" is of particular importance for implementing innovation activity in the region.

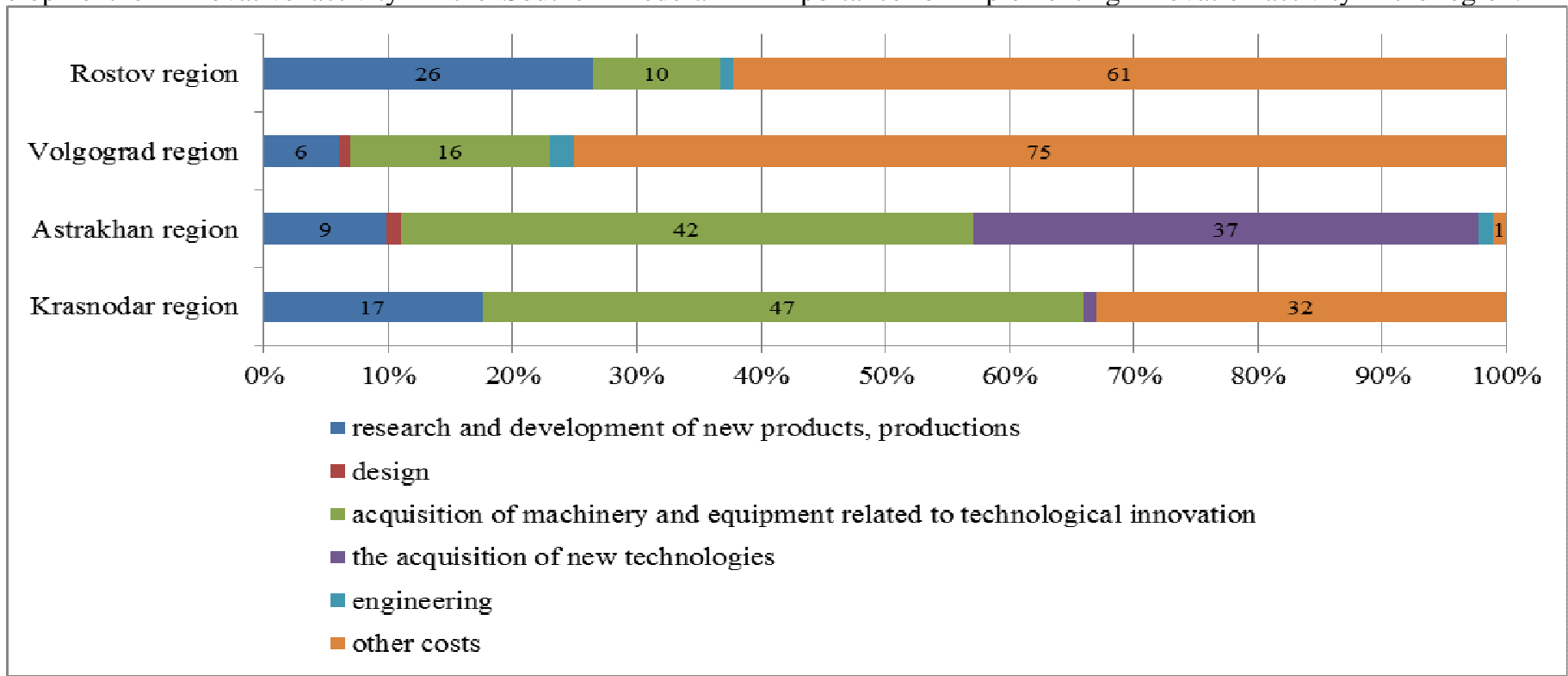

Figure 1 - The structure of expenditures on technological innovations by types of innovative activities in $2016, \%$

According to Russian Federal State Statistics Service (Table 1), the increase in the volume of shipped ownedproduced goods, performed owned-produced services in 2016 compared to 2015 in the region was $9.8 \%$, the growth rate of innovative goods, works and services increased by $19.3 \%$ against the decrease in the share of organizations engaged in technological and organizational innovations and low share of small enterprises (10\%), carrying out technological innovations, in the total number of small enterprises surveyed, indicating the concentration of innovation in the enterprises with significant investment and which are in the investment attractive sectors of the economy of the region.

Table 1 - Dynamics of the main indicators of innovation-active enterprises of the Astrakhan region, $\%$

\begin{tabular}{|l|l|l|l|l|l|l|}
\hline Indicators & 2011 & 2012 & 2013 & 2014 & 2015 & 2016 \\
\hline $\begin{array}{l}\text { Ratio of enterprises, engaged in technological } \\
\text { innovations }\end{array}$ & 5.2 & 5.2 & 8.1 & 11.6 & 11.8 & 8.6 \\
\hline $\begin{array}{l}\text { Ratio of enterprises, engaged in organizational } \\
\text { innovations }\end{array}$ & 0.5 & 1.6 & 2.0 & 2.6 & 2.4 & 1.8 \\
\hline $\begin{array}{l}\text { Percentage of costs for technological innovations in } \\
\text { the volume of shipped goods }\end{array}$ & 1.3 & 0.9 & 0.7 & 2.1 & 1.1 & 1.7 \\
\hline $\begin{array}{l}\text { Share of innovative goods, services in the volume } \\
\text { of shipped products }\end{array}$ & 2.8 & 0.7 & 1.8 & 4.9 & 5.4 & 5.8 \\
\hline
\end{tabular}

\section{RESULTS AND DISCUSSION}

Strategically important for the region are such economic activities as "extraction of fuel and energy minerals" and "production of vehicles and equipment", which account for about $30 \%$ of GRP and growth rates of production are $111.9 \%$ and $109.7 \%$ respectively.
The special economic zone of the region is positioned as a center of shipbuilding and production of components for the shipbuilding industry in the South of the Russian Federation, as well as a center for the production of equipment and construction of facilities for the development of hydrocarbon deposits on the Caspian shelf. 
By the end of 2017, there were eight residents on its territory: JSC "Shipbuilding yard "Lotus", LLC "Svoi", LLC"Medintekh", LLC "ATEF RUS", LLC "Hexa-Lotus", LLC "MKS", LLC "Protelyuks Lotus" and LLC "Inproekt".

The anchor resident of the SEZ "Lotus" is JSC " Shipbuilding yard " Lotus ", located on its territory, and the priority products of which include the construction of: high-cost tankers and chemical trucks with modern hull contours, construction and material, ensuring a reduction in operating costs and weight of the vessel by 10-15\%, and, accordingly, increased in 1.2-1.4 times the economic efficiency of transportation; dry cargo with an increased volume of cargo holds; passenger vessels of the PV300 project for 300 people of luxury class; passenger ships of the PKS180 project for 180 man of small draught for shallow river pools. Production capacities of the shipbuilding yard make it possible to build up to 3-4 cargo ship. However, the high import dependence on suppliers of ship equipment and components (about 50\%) and the absence of their own production in the region adversely affects the formation of the order portfolio of JSC "Lotus" and other shipbuilding companies.

In this regard, the preferential regime of the special economic zone in three key areas for business: state financing of infrastructure, tax and customs privileges, reduction of administrative barriers is an objective condition for the creation and development of small and medium-sized enterprises for the manufacture of ship equipment and components, as well as small innovative enterprises (SIE) that develop technological (including food and process) innovations in shipbuilding.

Creation and development of the specified enterprises is possible within integration with the anchor resident of SEZ of IPT "Lotus" in the form of the pool allowing accumulating financial resources of the shipbuilding enterprises and SIE for the development and commercialization of innovative products and technologies [4].

Thus, SIE are able to invest "pool" funds in the development of innovations at the early stages of the project and at the stage of commercialization of an innovative product.

Pooling is carried out in stages:

- studying the needs of shipbuilding enterprises of the region in research and innovative developments;

- organization and conducting of an active media campaign on the attractiveness of the SEZ IPT "Lotus" to accommodate small and medium-sized businesses in its territory;

-registration of the SIE as residents of the SEZ "Lotus";

- organization of the SIE work;

-creating a pool between SIE and JSC "Shipbuilding yard "Lotus";

- formation of a SIE order portfolio: conclusion of contracts for the supply of equipment, components, development of technological innovations and other types of works and services.

\section{CONCLUSION}

The conditions in special economic zones allow residents to reduce costs by $15-20 \%$ of the total cost for production.

Consequently, the management and operation of small innovative enterprises in the special economic zone will significantly reduce the cost for customs and tax payments, which will reduce the cost for innovative products and will create a competitive production of ship equipment and components for the construction of ships for various purposes in the region.

\section{References}

[1] New technological revolution: challenges and opportunities for Russia. Expert and analytical report. [Novaja tehnologicheskaja revoljucija: vyzovy i vozmozhnosti dlja Rossii. Jekspertno-analiticheskij doklad], Moscow, 2017. 136 p. Available at: http://csr.ru/wpcontent/uploads/2017/10/novaya-tehnologicheskayarevolutsiya-2017-10-13.pdf

[2] The Federal law of 22.07.2005 N 116-FZ (edition of 23.07.2013) "About special economic zones"[Federal'nyj zakon ot 22.07.2005 N 116-FZ (red. ot 23.07.2013) "Ob osobyh jekonomicheskih zonah"] Available at: http://www.sezlotos.ru/upload/iblock/9fb/federalnyi_zakon_n _116_fz.pdf-22 July. - No. 28. - pp. 36-39.

[3] E.V. Kryukova, "The Development of the Free Economic Zone in the Astrakhan Region: Myth and Reality"[Razvitie svobodnoj jekonomicheskoj zony Astrahanskoj oblasti: mif i real'nost']. Vestnik of Volgograd State University. Series 3, Economics. Ecology, 2017, No. 1 (38), pp. 62-67.

[4] E. P. Karlina and J. G. Levina, "The Development of Core Competencies of Shipbuilding Enterprises as the Basis for Strategic Cluster Management"[Razvitie bazovyh kompetencij sudostroitel'nyh predprijatij kak osnova strategicheskogo upravlenija klasterom]. Vestnik of Astrakhan State Technical University. Series: Economics. [Vestnik of Astrakhan State Technical University. Series: Economics], 2015, No. 1, pp. 38-46. 